\title{
INNOVATIVE METHODOLOGICAL TOOL FOR THE ASSESSMENT OF THE PERFORMANCE OF EDUCATIONAL INSTITUTIONS
}

\author{
M. S. Rakhmanova ${ }^{1}$ \\ V. V. Kryukov ${ }^{2}$
}

\begin{abstract}
The article describes a and extended by the fifth perspective theoretical and methodological approach to assessing the performance of educational facilities of general education on the basis of a balanced scorecard, which is a multifaceted approach to assessing performance, which encapsulates the elements of criteria-based and multi-factor approaches to assessing the performance of educational institutions. The paper also presents the methodological tools for assessing the performance of educational institutions, which is an expanded system "society". The overall performance of the educational institution makes it possible to evaluate the effectiveness of the activities taking into account the significance of the indicators of each perspective. A procedure for the formation of an information base and documentation support for assessing the performance of educational institutions which provides us with an opportunity to evaluate key indicators for assessing the performance of educational institutions has been developed.
\end{abstract} of balanced scorecard for assessing the performance of educational institutions, most fully reflecting the dynamics and current state of the performance of educational institutions in the four existing perspectives of the educational institution "finance", “customers", “internal processes", "potential and development"

Keywords: balanced scorecard, performance indicators, educational establishments of general education, perspectives for a balanced scorecard, overall performance indicator.

\section{INTRODUCTION}

${ }^{1}$ Federal State Budgetary Educational Institution of Higher Education "Vladivostok State University of Economics and Service", 41, Gogol Street, Vladivostok, Russia, email: russia@prescopus.com, https://orcid.org/0000-0002-4451-9619

${ }^{2}$ Federal State Budgetary Educational Institution of Higher Education "Vladivostok State University of Economics and Service", 41, Gogol Street, Vladivostok, Russia, email: editor@ores.su https://orcid.org/0000-0002-6763-7087 
Methods and indicators for assessing the performance of activities, which are usually used in Western companies, have been penetrating with Russian conditions relatively recently. One of the systems for determining the performance of a company is a system of balanced indicators - Balanced Scorecard (BSC), or a balanced scorecard system, which is a management system that enables managers to translate the organization's strategic goals into a specific plan of operational work of integrated companies.

The need to set up a system for assessing the quality of education at the school level is determined by the introduction of new educational standards and the need to assess their achievement at all levels. A performance evaluation system should be set up in educational institution, subsequent to the results of which reasoned managerial decisions will be made.

Therefore, an immediate problem is the improvement of methods and performance indicators of organizations, as the basis of good management. To solve this problem, it is necessary to justify a set of indicators and choose the best methods for the evaluation of the performance of organization. Thus, the topicality of the problems considered in the dissertation, its insufficient methodological elaboration have predetermined the purpose and objectives of the study, the choice of the object and the subject of scientific research.

\section{THE DEGREE OF SCIENTIFIC DEVELOPMENT OF THE PROBLEM}

The issues on improvement of the system of corporate management are covered by numerous research works by Russian and foreign scholars, among them are I. Ansoff, A. G. Porshnev, A. N. Tishchenko, N. A. Kizim, Y. V. Dogodailo, A. E. Voronkova, T. Y. Ivanova, V. I. Prihodko, N. V. Shashlo, G. V. Petruk, A. A. Korostelev and others. The obtained scholarly results make up methodological and theoretical background of the work [16].

The scholars such as I. A. Markina, V. N. Samochkin, D. S. Sink, I. P. Otenko, V. G. Ivanova, E. B. Gafforova and others give particular consideration to the problematics of corporate management performance assurance in a dynamically changing environment. The works by these authors formed the basis for recommendations on the development of management instrumentation adapted to industry conditions [7-12].

Issues of the performance of educational institutions over the past decades are in the focus of attention by the 
specialists, among which are: V. I. Zvereva, P. I. Tretyakov, P. Maximov, A. F. Gulevskaya, O. A. Gushchina, N. A. Samsikova, A. G. Kirillov, I. M. Syroezhin, I/I//, V. S. Vlasova and others. [13- 20].

\section{THEORETICAL AND}

METHODICAL APPROACH TO THE $\begin{array}{lrr}\text { ASSESSMENT } \quad \text { OF } & \text { THE } \\ \text { EFFECTIVENESS } & & \text { OF } \\ \text { EDUCATIONAL ORGANIZATIONS }\end{array}$

The theoretical and methodological approach to assessing the performance of education establishments is based on the concept of "effectiveness". For a better understanding of the essence of the concept of "effectiveness", it is advisable to consider the standards of ISO 9000: 2000 series, which define effectiveness as the degree of implementation of planned activities and achievement of planned results. Effectiveness should not be understood as a specific result of the organization's activity, but as the extent to which this result accomplishes an identified goal. Thus, effectiveness shows a complex relationship between the result (effect) and the goal of the organization. There are various approaches to assessing the performance of educational institutions, such as criteria-based, comprehensive and multifactorial, but the idea of combining a criteria-based, comprehensive and multifactorial approaches can be used through adapting the Norton-Kaplan BSC to the goals of managing an educational institution, and complementing it with a comprehensive technique of measurement managerial effectiveness coefficient [1727].

Characteristics of a strategic approach to the assessment of the effectiveness is presented in Table 1.

Table 1 - Characteristics of a Strategic Approach to the Assessment of the Effectiveness of Educational Establishments of General Education

\begin{tabular}{|l|l|}
\hline Aspects & Characteristic \\
\hline Nature of the approach & $\begin{array}{l}\text { It consists in identifying the strategic goals of the organization and assessing } \\
\text { how well the organization achieves these goals. }\end{array}$ \\
\hline
\end{tabular}


854

\begin{tabular}{|l|l|}
\hline Overall effectiveness criterion & $\begin{array}{l}\text { The coefficient of managerial effectiveness characterizes the degree of } \\
\text { attainment of central purpose of the organization. }\end{array}$ \\
\hline Partial effectiveness criteria & $\begin{array}{l}\text { It is selected by the main aspects of the organization. These are finances, } \\
\text { customers, internal processes, training and development for a commercial } \\
\text { organization. The list of prospects for an educational organization (school) } \\
\text { should be changed and supplemented by the "Society" perspective, for the } \\
\text { school has liability to the society for the results of their work. }\end{array}$ \\
\hline Sphere of application & $\begin{array}{l}\text { It can be used both for internal needs and for inner scorecard; it is used for } \\
\text { assessing at the operational and strategic level of management. }\end{array}$ \\
\hline
\end{tabular}

A methodological approach to activity effectiveness assessment complements all currently existing methods for assessing the performance of management of educational institutions. Ultimately, the use of several methods to evaluate the same object will allow for obtaining the most objective results.

\section{THE SYSTEM OF INDICATORS OF} ASSESSMENT OF EFFECTIVENES OF EDUCATIONAL

ORGANIZATIONS OF GENERAL EDUCATION

As a basis for developing a system of scorecard of effectiveness for educational institutions based on a strategic approach, the Norton-Kaplan balanced scorecard model has been applied.

A system of indicators for assessing the performance of educational institutions on the basis of a balanced scorecard, extended by the fifth perspective of "society".

The purpose of this system of indicators is to enhance the efficiency of education system at all levels - both at the level of an educational institution, and at the level of a municipality and a region.

In determining the performance indicators of educational institutions, the key success factors and strategic goals of 
each strategic economic zone are taken into account. Moreover, according to the methodology proposed by Norton and Kaplan, no more than two or three indicators are selected for each strategic goal of an educational institution. At this stage, of particular significance is the determination of leading indicators that can characterize not the results of the educational institution in previous periods, but its future performance. In a balanced scorecard, the transformation of the organization's strategy into terms of actions and tasks is carried out by means of "strategic maps" that define a set of causal relationships according to four perspectives (Figure 1).

In various sources, it is recommended for the state and non-profit structures to build a map of a balanced scorecard in which the "Clients" perspective is moved up the hierarchy. This recommendation is also suitable for schools due to the fact that the school is a budget institution.

Public funding is very important for the functioning of school. The school is essentially an agent of the state to provide free services to the population, therefore one of the main goals of the school, expressed in its mission, is to increase its own social significance and usefulness. Such significance and usefulness is determined by society satisfaction with the school performance, expressed in terms of quantity, quality, value and timeliness. This society satisfaction differs from customer satisfaction who is provided with the educational service, but unquestionably depends on it. Thus, the school should pursue the following two sets of goals:

- satisfaction of students and their parents with the products or services provided, depending on the organization of the school's internal processes, affecting, in particular, the image of school in society;

- satisfaction of society and state with the performance of school on the whole, depending on all aspects of school's activities, having influence, in particular, on the implementation of mission, as well as the financing of school by the state and non-profit foundations. 


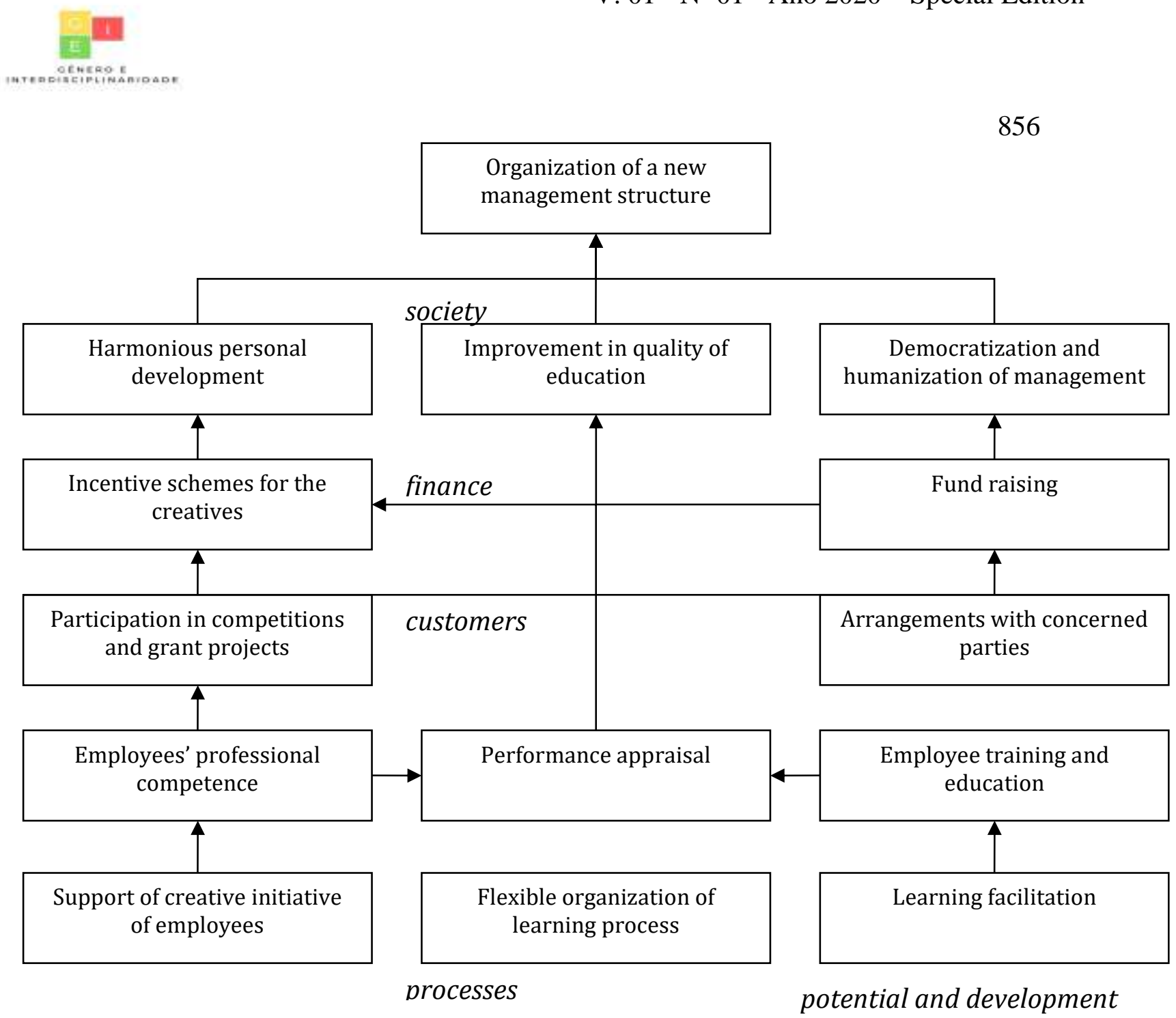

Figure1 - The Scheme of Strategic Map of an Educational Institution 
The first set of goals is reflected in the perspective of "Customers" of the strategic goals map of the balanced scorecard. To reflect the second group of school goals, it is proposed to form a fifth perspective called "Society". The formation of the fifth perspective does not contradict the general concept introduced by Norton and Kaplan who argue that in some cases the group of prospects can be expanded to reflect the specifics of the organization's activities [27]. Achieving the goals of the "Society" perspective for the school is a logical consequence of achieving all the goals of the subjacent perspective.

The strategic map shown in Figure 1 allows for the presentation of the strategy in the form of specific tasks for 5 perspectives of a balanced scorecard system adapted for school management: society, customers, processes, finances, potential and development (in the Norton-Kaplan BSC model: finances, customers, internal processes, training and development). Subsequently, this map with established relationships is supplemented by the necessary set of indicators.

The goal of the school in the field of management is the formation of a new management structure that ensures the activity of all participants in learning process.

In accordance with this goal the following tasks of intra-school management can be formulated:

- support for creative initiatives of school workers;

- flexible organization of learning process;

- creating comfortable conditions for learning.

The financial indicators traditionally incorporate revenue, various indicators of financial results (gross profit, profit from sales, profit from core and other activities before tax, net profit), profitability (sales, production, assets, equity, investments), etc. The financial indicators of school include: subsidies for the fulfillment of a state (municipal) assignment, targeted subsidies, budget investments, payroll budget, expenses on services, purchase of fixed assets, intangible assets, tangible assets.

It is customary to attribute the following to the indicators of the customer constituent part: customer's need satisfaction, maintaining the consumer base, attracting new customers, volume and share of the target market segment. For the school, 
the indicators of the "concerned parties" perspective should be indicators characterizing the degree of satisfaction of all interested parties: students, parents, municipal authorities, society as a whole (the latter seems to be important due to the high significance of the results of educational institutions for society).

It is proposed to use the following indicators of internal processes for school: school resourcing, staffing, organization of the educational process, education facilities for students, etc.

The indicators of the training and development section in the traditional system of a balanced scorecard are a set of general criteria (job satisfaction, staff turnover, training, advanced training) and specific factors, such as a detailed set of skills and abilities that are necessary for a new activity in a new competitive environment [25 ]. For schools, this list can be extended with the indicators of the quality of education, the competitiveness of school, growing influence on society, the intensification of the use of innovative technologies in schools, etc.

The list of key indicators of the effectiveness of educational institution (secondary school) developed on the basis of this model is presented in Table 2 [26].

Table 2 - The List of Key Indicators of the Effectiveness of an Educational Institution

\begin{tabular}{|c|c|}
\hline Perspective & Indicators \\
\hline Society & $\begin{array}{l}\text { - school image; } \\
\text {-performance of public management and administration; } \\
\text { - publishing on school activities in mass media; } \\
\text { - development of social partnership with higher schools and institutions } \\
\text { (organizations, establishments). }\end{array}$ \\
\hline Finance & $\begin{array}{l}\text { - absence of any comments on the inefficient budgetary allotment from financial } \\
\text { control authorities; } \\
\text { - presence of financial motivation system for teachers. }\end{array}$ \\
\hline $\begin{array}{l}\text { Potential and } \\
\text { development }\end{array}$ & $\begin{array}{l}\text { Indicators characterizing the results of innovation activity: } \\
\text { - performing innovation activities; } \\
\text { - organization and holding of workshops, meetings, conferences; } \\
\text { - participation of the school head teacher in professional contests, grants, projects, } \\
\text { scientific activities and their effectiveness; }\end{array}$ \\
\hline
\end{tabular}




\begin{tabular}{|c|c|}
\hline & $\begin{array}{l}\text { Indicators characterizing the development of the slate of internal talent: } \\
\text { - employees that are recognized by training program and advanced training } \\
\text { program; } \\
\text { - staff turnover. }\end{array}$ \\
\hline Customers & $\begin{array}{l}\text { - students' level of success in certain subjects; } \\
\text { - number of students at school; } \\
\text { - students' level of health; } \\
\text { - dynamics of the number of pupils and graduates registered with the commission } \\
\text { for the affairs of minors. }\end{array}$ \\
\hline Processes & $\begin{array}{l}\text { Indicators characterizing the conditions for the organization of the learning process: } \\
\text { - maintaining compulsory general education; } \\
\text { - compliance with federal state standards; } \\
\text { - provision with textbooks and teaching aids; } \\
\text { Personnel support indicators: } \\
\text { - staffing level; } \\
\text { - employment of recent graduates; } \\
\text { Indicators characterizing domestic climate: } \\
\text { - positive school atmosphere; } \\
\text { - arrangements for health improvement, rest and employment of students; } \\
\text { Resourcing indicators: } \\
\text { - upgrading of school facilities; } \\
\text { - quality preparation to school season; } \\
\text { - provision of aesthetic conditions; } \\
\text { Indicators of managerial performance: } \\
\text { - compliance with performance discipline of the school head teacher; } \\
\text { - regularly updated information on school site. }\end{array}$ \\
\hline
\end{tabular}

In developing a system of key indicators of the effectiveness of educational institution, certain requirements imposed on each of the coefficients are considered:

- each coefficient should be clearly defined, then any user will be able to measure it - including an employee whose performance is assessed using this indicator;

- the approved indicators and standards should be achievable: the goal should be real, but at the same time an incentive;

- the indicators should help motivate and increase the effectiveness 
of school personnel, and this is directly related to goal-setting;

- the indicators should be comparable;

- the dynamics of the coefficient should be presented visually (graphically) so that on the basis of the results it is possible to draw conclusions and make decisions;

- each indicator should be meaningful and be the basis for analysis.

The integrated performance indicator of an educational institution on the basis of the BSC is proposed to calculate by the formula (1):

$$
I_{P}=\sum_{i=1}^{5} d_{i} E_{i}
$$

where $d i$ - mean weighting coefficient of i perspective;

$$
E i \text {-mean value of }
$$

indicators of I perspective.

To the four Norton-Kaplan perspectives of BSC, we have added a fifth perspective - "society" - and developed indicators to evaluate it. The developed indicators and evaluation criteria allow us to evaluate the effectiveness of managing an educational institution in the areas of finance, customers, internal processes, potential and development. As a result, the strategic scorecard thus formed contributes to the implementation of the educational institution's strategy and the presented indicators will provide an educational institution with a universal mechanism that will reflect the school's strategy and the degree to which its objectives have been achieved.

\section{THE PARAMETERS OF INFORMATION BASE AND DOCUMENTARY SUPPORT OF ASSESSMENT OF \\ PERFORMANCE OF GENERAL EDUCATION ORGANIZATIONS}

A necessary element of the information provision of the analysis of balanced scorecard is regulatory and planning information, the use of which will allow us to analyze the main indicators for their compliance with the chosen strategy, and also use it to form indicators of the educational institution plan for subsequent periods. Attracting the earlier normative planning data in an educational institution, in the process of analysis, the main indicators of the educational institution's plan for the coming period are developed and internal standards are specified. 
Regulatory material is

contained in the following documents of the educational institution:

\section{- information}

on

accreditation of an educational institution;

- charter of an educational

institution;

- educational institution

license;

- order approving the

educational program and the educational program of an institution;

- educational institution

curriculum;

- classroom journal

regulation;

- $\quad$ class teacher regulation;

- internal education

evaluation regulation;

- regulation of the work

with the poorly performing students;

- regulation of student's

transferring, resuming studies and expelling;

- regulation of students'

knowledge assessment system according to Federal Educational Standard;

- collective agreement;

- regulation of the

commission for the settlement of disputes between participants in

educational relations;

- $\quad$ passport of road safety of an educational institution;

- internal labor regulations;

- passport school health

camp;

- $\quad$ regulation on the Council

of an educational institution;

- $\quad$ regulation on the Board of

Trustees;

- order of current control and intermediate certification of students;

- regulation on the

remuneration of teachers;

- order on approval of tariffs for for-profit education.

- rules of students'

behavior.

To assess the internal processes, as well as the potential and development of an educational institution, it is advisable to use the following documents:

- public report of an educational institution;

- $\quad$ report on the results of the educational institution;

- report on selfexamination of an educational institution, etc. 
In our opinion, the greatest value for the formation and analysis of a system of balanced indicators is represented by the organization's accounting information, which include accounting and reporting, operational accounting and reporting, statistical accounting and reporting, and sample accounting data.

An important source of information for evaluating a balanced scorecard is statistical data and reporting data, which can be used to identify trends of the main indicators of BSC, as well as the degree of their uncertainty and risk. For example, information about the results of an educational institution is the basis for the entire forecast analysis system.

Selected accounting data are required when conducting an in-depth analysis of certain aspects of the current and future financial performance of the organization. Such information is presented by data from episodic samples, observations, and limited scope audit.

To a greater extent, information support of the financial aspect of the balanced scorecard is provided via application of accounting (financial) statements or, to a somewhat broader extent, accounting data. The following documents form the information base for assessing the financial component of the educational institution's performance:

- report on the financial results of an educational institution;

- balance of state (municipal) institution;

- plan of financial and economic activity of an educational institution;

- report on implementation of the plan of financial and economic activity of an educational institution.

In a balanced scorecard, causal relationships between goals, the development of indicators and actions to be performed to achieve the goals should be clearly traced. This is essential in order to manage an educational institution and to understand what can affect any of the indicators. Management decisions for the "Finance" perspective are presented in Table 3.

Feasible and unfeasible values for each educational institution should be determined individually, taking into account its features. According to Table 3 , if the planned values for the "Finance" perspective have not been achieved, the leadership of the educational institution must make decisions aimed at 
accounting the values of financial

indicators for the normative (desirable)

ones for this educational institution.

Table 3 - The Variants of Management Decisions on the "Finance" Perspective

\begin{tabular}{|c|c|c|}
\hline \multirow{2}{*}{ Indicator } & \multicolumn{2}{|l|}{ Indicator value } \\
\hline & Feasible & Unfeasible \\
\hline $\begin{array}{l}\text { Absence of any } \\
\text { comments and } \\
\text { irregularities in the } \\
\text { process of activity } \\
\text { during the audit of } \\
\text { controlling finance } \\
\text { bodies }\end{array}$ & $\begin{array}{l}\text { Maintenance of lack of comments and } \\
\text { irregularities }\end{array}$ & $\begin{array}{l}\text { Conducting an internal audit, } \\
\text { identifying and eliminating } \\
\text { the causes of irregularities }\end{array}$ \\
\hline $\begin{array}{l}\text { Budgetary } \\
\text { appropriations for } \\
\text { school }\end{array}$ & $\begin{array}{l}\text { Maintenance of the regime of school support at } \\
\text { the expense of budget assignments, introduction } \\
\text { of budget savings }\end{array}$ & $\begin{array}{l}\text { Analysis of the expenditure } \\
\text { patterns and their } \\
\text { optimization }\end{array}$ \\
\hline $\begin{array}{lr}\text { No overdue } \\
\text { payables and } \\
\text { receivables }\end{array}$ & $\begin{array}{l}\text { Maintaining payment discipline by developing a } \\
\text { payment schedule }\end{array}$ & $\begin{array}{l}\text { Analysis of work with } \\
\text { debtors and creditors, search } \\
\text { for reserves for timely } \\
\text { payment of accounts payable }\end{array}$ \\
\hline $\begin{array}{l}\text { Extrabudgetary } \\
\text { funds }\end{array}$ & Extrabudgetary fundraising & $\begin{array}{l}\text { Search for ways to increase } \\
\text { the volume of extrabudgetary } \\
\text { resource }\end{array}$ \\
\hline
\end{tabular}


864

\begin{tabular}{|c|c|c|}
\hline $\begin{array}{l}\text { Expenses for } \\
\text { renumeration paid } \\
\text { to executive staff, } \\
\text { educational } \\
\text { support staff and } \\
\text { service staff }\end{array}$ & $\begin{array}{l}\text { Maintenance of the regime saving expenses for } \\
\text { renumeration to be paid to managerial, } \\
\text { educational support and service staff }\end{array}$ & $\begin{array}{l}\text { Reduction of expenses for } \\
\text { renumeration to be paid to } \\
\text { managerial, educational } \\
\text { support and service staff }\end{array}$ \\
\hline
\end{tabular}

Table 4 considers the variants of managerial decisions for the perspective of "Customers".

As it follows from the data presented in Table 4, if the planned values have not been achieved or the values of the indicators have been reduced in the "Customers" perspective, the organization makes two types of management decisions: the first type of decisions is aimed at eliminating the problem and the reasons for its occurrence; the second - at maintaining high indicator values. Table 5 considers the variants of managerial decisions for the perspective of "Internal Processes".

Table 4 - The Variants of Managerial Decisions for the Perspective of "Customers"

\begin{tabular}{|c|c|c|}
\hline \multirow{2}{*}{ Indicator } & \multicolumn{2}{|l|}{ Indicator values } \\
\hline & Feasible & Unfeasible \\
\hline $\begin{array}{l}\text { The dynamics of individual } \\
\text { learning outcomes of students, } \\
\text { final academic assessment }\end{array}$ & $\begin{array}{l}\text { Maintaining high } \\
\text { performance results }\end{array}$ & $\begin{array}{l}\text { Analysis of the causes of unsatisfactory } \\
\text { results, increased results }\end{array}$ \\
\hline $\begin{array}{l}\text { Variation of the results of the } \\
\text { unified national }\end{array}$ & $\begin{array}{l}\text { Maintaining variation } \\
\text { indicators }\end{array}$ & $\begin{array}{l}\text { Analysis of the causes of unsatisfactory } \\
\text { results, increased results }\end{array}$ \\
\hline Number of students in school & $\begin{array}{l}\text { Maintenance of stable } \\
\text { supply }\end{array}$ & $\begin{array}{l}\text { Analysis of the reasons, development } \\
\text { of measures to maintain a constant } \\
\text { amount }\end{array}$ \\
\hline
\end{tabular}


865

\begin{tabular}{|l|l|l|}
\hline Students' health & $\begin{array}{l}\text { Maintaining a high } \\
\text { indicator value }\end{array}$ & $\begin{array}{l}\text { Elaboration of measures to improve } \\
\text { students' health level }\end{array}$ \\
\hline
\end{tabular}

Table 5 - The Variants of Managerial Decisions for the Perspective of "Internal

Processes"

\begin{tabular}{|c|c|c|}
\hline \multirow{2}{*}{ Indicator } & \multicolumn{2}{|l|}{ Indicator value } \\
\hline & Feasible & Unfeasible \\
\hline $\begin{array}{l}\text { Ensuring compulsory general } \\
\text { education (the safety of the contingent } \\
\text { within the same educational level) }\end{array}$ & $\begin{array}{l}\text { Maintaining } \\
\text { compulsory } \\
\text { general } \\
\text { education }\end{array}$ & Enhancing school enrollment \\
\hline $\begin{array}{l}\text { Implementation of subject-oriented } \\
\text { instruction, pre-specialized training }\end{array}$ & $\begin{array}{l}\text { Maintaining } \\
\text { educational } \\
\text { programs of } \\
\text { subject-oriented } \\
\text { instruction, pre- } \\
\text { specialized } \\
\text { training }\end{array}$ & $\begin{array}{l}\text { Implementing, developing educational } \\
\text { programs of subject-oriented instruction, } \\
\text { pre-specialized training }\end{array}$ \\
\hline Teaching staffing levels & $\begin{array}{l}\text { Maintaining a } \\
\text { high indicator } \\
\text { value }\end{array}$ & $\begin{array}{l}\text { Problem searching, strengthening of } \\
\text { teaching staff }\end{array}$ \\
\hline $\begin{array}{l}\text { Provision of schools with textbooks } \\
\text { and recourse material }\end{array}$ & $\begin{array}{l}\text { Maintaining a } \\
\text { high indicator } \\
\text { value }\end{array}$ & $\begin{array}{l}\text { Purchasing of textbooks and resource } \\
\text { material with the use of extrabudgetary } \\
\text { resources }\end{array}$ \\
\hline $\begin{array}{l}\text { Ratio of students being educated in } \\
\text { schools equipped with updated } \\
\text { facilities }\end{array}$ & $\begin{array}{l}\text { Maintaining a } \\
\text { high indicator } \\
\text { value }\end{array}$ & $\begin{array}{l}\text { Implementation of new technologies } \\
\text { making allowance for being educated in } \\
\text { schools equipped with updated facilities }\end{array}$ \\
\hline $\begin{array}{l}\text { Measures implementation on school } \\
\text { recruiting }\end{array}$ & $\begin{array}{l}\text { Maintaining a } \\
\text { high indicator } \\
\text { value }\end{array}$ & $\begin{array}{l}\text { Elaboration of measures on school } \\
\text { recruiting }\end{array}$ \\
\hline Grade of qualification & $\begin{array}{l}\text { Maintaining a } \\
\text { high indicator } \\
\text { value }\end{array}$ & $\begin{array}{l}\text { Elaboration of measures on advanced } \\
\text { training }\end{array}$ \\
\hline
\end{tabular}


866

\begin{tabular}{|c|c|c|}
\hline $\begin{array}{l}\text { Safety of participants in learning } \\
\text { process }\end{array}$ & $\begin{array}{l}\text { Maintaining a } \\
\text { high indicator } \\
\text { value }\end{array}$ & $\begin{array}{l}\text { Elaboration of measures on improvement } \\
\text { of safety of participants in learning } \\
\text { process }\end{array}$ \\
\hline Health saving event planning & $\begin{array}{l}\text { Maintaining a } \\
\text { high indicator } \\
\text { value }\end{array}$ & $\begin{array}{l}\text { Elaboration and implementation of health } \\
\text { saving measures }\end{array}$ \\
\hline $\begin{array}{l}\text { Implementation of measures for the } \\
\text { prevention of juvenile delinquency }\end{array}$ & $\begin{array}{l}\text { Maintaining a } \\
\text { high indicator } \\
\text { value }\end{array}$ & $\begin{array}{l}\text { Elaboration of measures for the prevention } \\
\text { of juvenile delinquency }\end{array}$ \\
\hline $\begin{array}{l}\text { Preparation of school for a new } \\
\text { academic year }\end{array}$ & $\begin{array}{l}\text { Maintaining a } \\
\text { high indicator } \\
\text { value }\end{array}$ & $\begin{array}{l}\text { Improving the quality of school } \\
\text { preparation for a new academic year }\end{array}$ \\
\hline Arrangements for feeding & $\begin{array}{l}\text { Maintaining a } \\
\text { high indicator } \\
\text { value }\end{array}$ & Improving arrangements for feeding \\
\hline \multirow[t]{2}{*}{ Indicator } & Indicator value & \\
\hline & Feasible & Unfeasible \\
\hline Upgrade of facilities and resources & $\begin{array}{l}\text { Maintaining a } \\
\text { high indicator } \\
\text { value }\end{array}$ & Revision of facilities and resources \\
\hline $\begin{array}{l}\text { Ensuring aesthetic conditions, design } \\
\text { (compliance with the developing } \\
\text { environment, compliance with sanitary } \\
\text { and hygienic requirements) }\end{array}$ & $\begin{array}{l}\text { Maintaining a } \\
\text { high indicator } \\
\text { value }\end{array}$ & Improved aesthetic conditions \\
\hline $\begin{array}{l}\text { Level of performance discipline of } \\
\text { employees }\end{array}$ & $\begin{array}{l}\text { Maintaining a } \\
\text { high indicator } \\
\text { value }\end{array}$ & Improving performance discipline \\
\hline $\begin{array}{l}\text { School site operates and is being } \\
\text { upgraded }\end{array}$ & $\begin{array}{l}\text { Maintaining a } \\
\text { high indicator } \\
\text { value }\end{array}$ & $\begin{array}{l}\text { Assigning responsibility for working with } \\
\text { the site and monitoring performance }\end{array}$ \\
\hline $\begin{array}{l}\text { Engagement of students in club } \\
\text { activities in school }\end{array}$ & $\begin{array}{l}\text { Maintaining a } \\
\text { high indicator } \\
\text { value }\end{array}$ & Enlargement of club activities \\
\hline $\begin{array}{l}\text { Opportune correct internal and external } \\
\text { reporting }\end{array}$ & $\begin{array}{l}\text { Maintaining a } \\
\text { high indicator } \\
\text { value }\end{array}$ & $\begin{array}{l}\text { Reporting analysis. Identification of } \\
\text { problems and elimination of the reasons }\end{array}$ \\
\hline
\end{tabular}


If the standard values of indicators for the "Internal Processes" perspective have not been achieved, the management of the educational institution makes managerial decisions to update the technology, enhance learning outcomes, increase resource capability, raise the level of staff skills and increase their engagement, etc. Table 6 considers the variants of managerial decisions for the perspective of "Potential and Development".

Table 6 - The Variants of Managerial Decisions for the Perspective of "Potential and

Development"

\begin{tabular}{|c|c|c|}
\hline \multirow{2}{*}{ Indicator } & \multicolumn{2}{|l|}{ Indicator value } \\
\hline & Feasible & Unfeasible \\
\hline $\begin{array}{l}\text { Presence of students who have } \\
\text { become winners or prize-winners } \\
\text { of subject Olympiads, research-to- } \\
\text { practice conferences, creativity } \\
\text { competitions }\end{array}$ & $\begin{array}{l}\text { Maintaining a high } \\
\text { indicator value }\end{array}$ & $\begin{array}{l}\text { Interviewing and testing, finding talented } \\
\text { students, organizing work with gifted } \\
\text { children }\end{array}$ \\
\hline $\begin{array}{l}\text { Meaningful participation of } \\
\text { management in professional skills } \\
\text { competitions, research-to-practice } \\
\text { conferences, scientific workflows }\end{array}$ & $\begin{array}{l}\text { Maintaining a high } \\
\text { indicator value }\end{array}$ & $\begin{array}{l}\text { Development and implementation of a } \\
\text { leadership participation program in } \\
\text { professional skills competitions, grants, } \\
\text { projects, research-to- practice } \\
\text { conferences, scientific activities }\end{array}$ \\
\hline $\begin{array}{l}\text { Participation in innovations, } \\
\text { conducting experimental work }\end{array}$ & $\begin{array}{l}\text { Maintaining a high } \\
\text { indicator value }\end{array}$ & $\begin{array}{l}\text { Gaining a status of REU,RRP, base site, } \\
\text { scientific and methodological } \\
\text { publications }\end{array}$ \\
\hline $\begin{array}{l}\text { Implementation of programs } \\
\text { aimed at working with gifted } \\
\text { children }\end{array}$ & $\begin{array}{l}\text { Maintaining a high } \\
\text { indicator value }\end{array}$ & $\begin{array}{l}\text { Interviewing and testing, finding talented } \\
\text { students, organizing work with gifted } \\
\text { children }\end{array}$ \\
\hline $\begin{array}{l}\text { Formation of an appropriate } \\
\text { learning environment for various } \\
\text { categories of students }\end{array}$ & $\begin{array}{l}\text { Maintaining a high } \\
\text { indicator value }\end{array}$ & $\begin{array}{l}\text { Analysis of the contingent of students, } \\
\text { development of recommendations for the } \\
\text { formation of an appropriate learning } \\
\text { environment. }\end{array}$ \\
\hline $\begin{array}{l}\text { Number of employees trained in } \\
\text { vocational and continuing } \\
\text { education programs }\end{array}$ & $\begin{array}{l}\text { Maintaining a high } \\
\text { indicator value }\end{array}$ & $\begin{array}{l}\text { Enumeration of employees taking } \\
\text { vocational retraining and advanced } \\
\text { training to programs. Budget } \\
\text { optimization. }\end{array}$ \\
\hline
\end{tabular}


868

\begin{tabular}{|l|l|l|}
\hline Stability of staff structure & $\begin{array}{l}\text { Maintaining a high } \\
\text { indicator value }\end{array}$ & $\begin{array}{l}\text { Identification of causes of dismissal, } \\
\text { elaboration of incentive scheme. }\end{array}$ \\
\hline $\begin{array}{l}\text { Coefficient of personnel's } \\
\text { satisfaction with labor conditions }\end{array}$ & $\begin{array}{l}\text { Maintaining a high } \\
\text { indicator value }\end{array}$ & $\begin{array}{l}\text { Discovery of reasons for dissatisfaction, } \\
\text { improvement of labor organization }\end{array}$ \\
\hline
\end{tabular}

The variants of managerial decisions presented in Table 6 for the perspective of "Potential and Development" offer the leadership of an educational institution the choice of the alternatives as a result of the institution's achieving or not achieving certain standard values of indicators that are individual for each educational institution.

\section{CONCLUSION}

The analysis provides us with an opportunity to highlight the advantages of the criteria-based, integrated and multifactorial approach to assessing the performance of educational institutions of general education and, based on their analysis, to propose a strategic approach to assessing the performance of educational institutions. From our point of view, the idea of combining a criteria-based, integrated and multifactorial approach can be used by adapting the BSC proposed by Norton and Kaplan to the goals of managing an educational institution, and by complementing it with a comprehensive methodology for measuring the coefficient of managerial performance.

The BSC model proposed by Norton and Kaplan as the most promising and universal, and as such having the most important advantages from the point of view of management analysis, has been taken as a basis for the formation of a system of indicators for assessing the performance of educational institutions. With account taken of possible goals and objectives of the development of the educational institution (school), we have proposed a list of indicators that most fully reflects the dynamics and current state of performance on the five perspectives of an educational institution: society, finance, customers, internal processes, potential and development. Since the reliability of the analysis of indicators of a balanced system directly depends on the accuracy and exhaustiveness of the information used, the information base that provides it should embrace all aspects of an educational institution. 
The proposed methodology is universal and can be used in any educational institutions. Its application will make it possible to assess the actual degree of implementation of the strategic goals of educational institutions and make timely alterations to the management process.

\section{THE CONFLICT OF INTERESTS}

The authors confirm that the data presented do not contain any conflict of interests.

\section{REFERENCES}

Ansoff I. Strategic Management / I. Ansoff. - M.: Economics, 2012. - 520 p. Porshnev A. G. The Quality, Performance and Effectiveness of Management [Electronic resource] // The "Elitarium" Center for Distance Education. - 2010. - Issue 4-5. - Access Mode:

http://www.elitarium.ru/2010/04/05/kac hestvo_menedzhmenta.html.

Tishchenko A. N. Economic Performance of Enterprises: Monograph / A. N. Tishchenko, N. A. Kizim, Y. V. Dogogailo. - K.: Inzhek, 2010. - 144 p.
Organization Theory / T. Y. Ivanova, V. I. Prikhodko. - St. Petersburg: Peter, 2014. - 269 p.

Voronkova A.E. Strategic Management of the Enterprise Competitive Potential: Diagnostics and Organization: Monograph / A. E. Voronkova. Lugansk: EUNU, 2010. - 316 p.

Shashlo N.V., Petruk G.V., Korostelev A.A. Determinants of integration interaction among the subjects of the entrepreneurial innovation ecosystem of macro region // Amazonia Investiga. 2018. T. 7. № 13. C. 351-363.

Markina I. A. Methodology of Effective Management / I. A. Markina // Finance. - 2010. - Issue 6. - P. 24-32.

Samochkin V. N. Assessment of Innovation Capabilities of the Enterprise and Their Use in the Formation of LongTerm Development Plans / V. N. Samochkin, O. A. Timofeyeva, A. A. Kolyukin // Management in Russia and Abroad. - 2012. - Issue 6. - P. 12-21.

Otenko I. P. Methodological Foundations of Enterprise Potential Management / I. P. Otenko. - K.: KNEU, 2014. - $216 \mathrm{p}$.

Sink D. S. Performance Management: Planning, Measurement and Evaluation, Control and Improvement / D. S. Sink. M.: Progress, 2010. - 528 p. 
Gafforova E. B. Organizational and Methodological Foundations of Quality Management in an Integrative Enterprise Management System: Dissertation for Doctor of Economic Sciences / E. B. Gafforova. - SP., 2009. - 341 p.

Petruk G.V., Shashlo N.V. Implementation of the science development strategy: new and non$\underline{\text { standard solutions } / / \quad \underline{\text { Dilemas }}}$ contemporáneos: Educación, Política y Valores. 2019. V. 7. № 1. P. 57. https://elibrary.ru/item.asp?id=4282984 1

Zvereva V. I. School Self-Certification / V. I. Zvereva. - M.: The Pedagogical Search Educational Center, 1999.

Tretyakov P.I. Formation and Development of School Management System: Dissertation for Doctor of Education / P. I. Tretyakov. - M., 1997. Modern Means of the Regional System for Assessing the Quality of Education / V. P. Maximov, A. F. Gulevskaya, O. A. Gushchina, N. A. Samsikova. - YuzhnoSakhalinsk: The SakhSU Publishing House, 2011. - 328 p.

Kirillov A. G. Assessment of the Effectiveness of the University Management System [Electronic resource] // Access Mode: http://mggush.ru/sites/default/files/kirillov_0.pdf.
Syroezhin I. M. Improving the System of Indicators of Efficiency and Quality / I. M. Syroezhin. - M.: Book on Demand, 2012. - 192 p.

Shashlo N.V., Petruk G.V. Consumer Value of Knowledge in the Innovation Ecosystem of the Russian Far East // University Management: Practice and Analysis.2017. Volume. 21. Issue 5 (111). P. 93-102

Petruk G.V. Quality assessment system for teaching activities // Revista San Gregorio. 2019. № 32. P. 145-149.

The "Implementation of the Model of Education Quality Management System in Educational Institutions of the Novosibirsk Region" Project [Electronic resource] // Access Mode: http://17classgim.ru/DswMedia/proekts ukonso.pdf.

Performance Indicators for the Deputy Director of the Public Educational Institution of Secondary School 32 of Vorkuta [Electronic resource] // Access Mode:

https://docviewer.yandex.ru/?url=http\% 3A\%2F\%2Fschool32.my1.ru2F_tbkp\% 2Fkriterii.

doc \&name $=$ kriterii.doc $\&$ lang $=\mathrm{ru} \& \mathrm{c}=57$ 2a0a549e14.

Methodology for the Analysis of Quality and Effectiveness of Management at 
Ugra College [Electronic Resource] // Access

Mode:

http://www.ugrakor.ru/files/

_filename_794_1299.pdf.

Methodology for the Rating of

Secondary Schools in Moscow

[Electronic Resource] // Access Mode:

http://kapital-

rus.ru/articles/article/234408/.

Zenkina I.V. Fundamentals of Forming a

System of Indicators of an Economic

Entity in Line with Modern Concepts of

Strategic Management / I.V. Zenkina //

Economic Analysis: Theory and

Practice. - 2009. - Issue 27. - P. 18.

Mikheyenko Y. V. Cascading a

Balanced Scorecard According to

Hierarchy Levels in the Organizational

Structure of a Company. Economic and

Applied Problems of System

Management in a Crisis: Collection of

Works / Edited by V. I. Khabarov. - M.:

Moscow Finance and Industry Academy; DS Market. - 2011. - 304. p. 57

Lugovoi R.A., Solodukhin K.S., Chen A.Y. A Method for Formalizing the Relationship Between the Level of Achievement of a Strategic Goal and Its Indicators // University Management: Practice and Analysis. 2012. Issue 1 (77). P. 19-25.
Kaplan R. Balanced Scorecard. From

Strategy to Action / Robert S. Kaplan,

David P. Norton. - M .: Olympus

Business. -2014 . $-456 \mathrm{p}$ 